Article

\title{
Effects of Phytase Supplementation to Diets with or without Zinc Addition on Growth Performance and Zinc Utilization of White Pekin Ducks
}

\author{
Youssef A. Attia ${ }^{1,3}{ }^{(0)}$, Nicola F. Addeo ${ }^{2}$, Abd Al-Hamid E. Abd Al-Hamid ${ }^{3}$ and Fulvia Bovera ${ }^{2, *}$ \\ 1 Arid Land Agriculture Department, Faculty of Meteorology, Environment and Arid Land Agriculture, \\ King Abdulaziz University, Jeddah 21589, Saudi Arabia; yaattia@kau.edu.sa \\ 2 Department of Veterinary Medicine and Animal Production, University of Napoli Federico II, 80137 Napoli, \\ Italy; nicolafrancesco.addeo@unina.it \\ 3 Department of Animal and Poultry Production, Faculty of Agriculture, Damanhour University, Damanhour, \\ Egypt; abd_abd_el_hamid_agric@yahoo.com \\ * Correspondence: bovera@unina.it
}

Received: 28 March 2019; Accepted: 21 May 2019; Published: 25 May 2019

check for updates

Simple Summary: The environment sustainability of farms is extremely important for the future of the world. In this context, the lowering of the pollution from intensive poultry farms is necessary. Due to its low levels and low digestibility in feeds, $\mathrm{Zn}$ is often overdosed in poultry feed, and its excess in the excreta can accumulate in the soil, inhibiting the growth of soil microorganism as well as altering their morphology and metabolism, thus reducing the crop yield and quality. Enzymes, such as phytase, can breakdown the linkage of $\mathrm{Zn}$ with phytic acid in vegetable feeds, thus increase the $\mathrm{Zn}$ availability for animal digestion. In this way, very low supplementation of $\mathrm{Zn}$ to the diets can meet the requirement of poultry.

Abstract: The effect of phytase and inorganic Zn supplementation was studied in 180 male White Pekin ducks (WPD) from 1 to 56 days of age. The birds were divided into four groups fed the same basal diet (containing $26 \mathrm{ppm}$ of $\mathrm{Zn}$ from raw materials): the control group did not receive $\mathrm{Zn}$ supplementation; the second group was supplemented with $30 \mathrm{ppm}$ of $\mathrm{Zn}$ oxide; and the third and fourth groups were fed the control and the $30 \mathrm{ppm}$ diets, respectively, both supplemented with $500 \mathrm{U}$ of E. coli phytase. Each group contained five replicates of nine ducks. The body weight and feed intake were recorded at 1, 28 and 56 days of age. At 56 days of age, five birds/group were used to measure feed digestibility and five other birds/group were slaughtered. $\mathrm{Zn}$ at $30 \mathrm{ppm}$ increased the body weight gain (BWG, $p<0.01)$ and feed intake $(p<0.05)$ and improved the feed conversion (FCR, $p<0.05)$ of the growing ducks. The $\mathrm{Zn}$ retention and $\mathrm{Zn}$ level in the excreta increased $(p<0.01)$ due to Zn supplementation. The addition of phytase improved BWG $(p<0.01)$ and FCR $(p<0.05)$ of growing ducks. The use of phytase reduced $(p<0.01)$ the level of $Z n$ in duck excreta. Phytase supplementation to the basal diet at $30 \mathrm{ppm}$ seems to be adequate to meet $\mathrm{Zn}$ requirements for ducks without further $\mathrm{Zn}$ additions.

Keywords: ducks; zinc oxide; phytase; growth performance; zinc utilization

\section{Introduction}

Zinc $(\mathrm{Zn})$ is an essential trace mineral with several roles in animal metabolism, acting as a functional component of more than 200 enzymes [1,2]. In the NRC guidelines [3], Zn requirements for ducks are not provided; therefore, the dietary requirement of $\mathrm{Zn}$ for ducks is based on those for other bird species. 
In poultry nutrition, $\mathrm{Zn}$ is required for eggshell deposition [4]; inadequate amount of $\mathrm{Zn}$ negatively affects the feed intake, growth rate and feed conversion ratio of broilers [5]. In addition, abnormalities in the immune responses, as well as reproduction, skeletal and skin disorders can be tied to the deficiency of $\mathrm{Zn}$ in poultry diets [6].

In general, the level of $\mathrm{Zn}$ in feedstuffs is low [3] and in vegetable products this element is also poorly available for digestion because its chelation to the phytic acid [7]. Thus, the addition of $\mathrm{Zn}$ to poultry diets is a common practice. A comparison between NRC [3] recommendation and modern commercial strains of broilers suggests that industries often use a big safety margin of $\mathrm{Zn}$ in feed formulation [5], also considering that amount of $\mathrm{Zn}$ up to $2000 \mathrm{mg} / \mathrm{kg}$ in poultry diets does not negatively affect the bird performance [8]. However, high amount of $\mathrm{Zn}$ in the diets is responsible of the high excretion of this trace element into the environment [9] as fecal $\mathrm{Zn}$ content linearly increases with Zn dietary levels [10]. Thus, the European Commission has recently established a maximum limit for the total $\mathrm{Zn}$ content, including the supplemental premix, of poultry diets at $100 \mathrm{ppm}$ [11]. Therefore, the knowledge of the specific $\mathrm{Zn}$ requirements can reduce its supplementation in poultry diets, without affecting animal health, welfare and productivity [2].

A possible solution could be the use of enzymes associated with vegetables. Phytase is a useful additive that improves the nutritive value of feedstuffs rich in phytic acid and also reduces environmental pollution related to nitrogen, and several metals $(\mathrm{Cu}, \mathrm{Zn}, \mathrm{Fe}$, and $\mathrm{Mg})$ by improving their availability to the animal and decreasing their excretion into the environment [12-16]. Yu et al. [17] indicated that phytate reduces the $\mathrm{Zn}$ absorption in the broiler intestinal tract; therefore, it can be hypothesized that adding the phytase to the diets, the amount of $\mathrm{Zn}$ available for poultry digestion can be increased.

The objective of this study was to investigate the effects of phytase supplementation to diets with or without $\mathrm{Zn}$ addition on productive performance and physiological traits of growing ducks. The addition of phytase to the diet with $\mathrm{Zn}$ oxide aimed to verify if only the supplementation of inorganic $\mathrm{Zn}$ is enough to sustain animal performance or if more $\mathrm{Zn}$ can provide further improvements.

\section{Materials and Methods}

\subsection{Experimental Design, Birds, Diets, and Husbandry}

All procedures were approved by the Animal and Poultry Production Department, Faculty of Agriculture, Damanhour University (Egypt) that recommends animal rights and welfare.

One hundred eighty one-day-old male White Pekin ducks (Anas platyrhynchos domestica, WPD) were homogeneously distributed into four groups fed the same starter and finisher diets (basal diets). The groups were subjected to four dietary treatments as follow: the first group (control) was fed basal diets unsupplemented with $\mathrm{Zn}$ oxide or phytase; the second group was fed the basal diets supplemented with $30 \mathrm{ppm}$ of $\mathrm{Zn}$ oxide $(72 \% \mathrm{Zn})$; the third group was fed the basal diets supplemented with $500 \mathrm{U}$ of E. coli phytase (E. coli 6-phytase, 500 U/kg diet; Danisco Animal Nutrition, England); and the fourth group was fed the basal diets supplemented with $30 \mathrm{ppm}$ of $\mathrm{Zn}$ oxide and $500 \mathrm{U}$ of E. coli phytase. The basal (starter and finisher) diets were obtained by using a $Z n$-free trace mineral mixture and contained $26 \mathrm{ppm}$ of $\mathrm{Zn}$ from raw materials without $\mathrm{Zn}$ supplementation, as measured by Atomic Absorption Spectrometry analysis. The starter diet (fed from 1 to 35 days of age) and the finisher diet (36-56 days of age) were formulated according to NRC [3] recommendations and their ingredients and chemical-nutritional characteristics [18] are reported in Table 1. 
Table 1. Ingredients and chemical-nutritional characteristics of the basal diets fed to White Pekin ducks during the starter (1-35 days of age) and the finisher (36-56 days) periods.

\begin{tabular}{|c|c|c|c|c|}
\hline \multirow{2}{*}{$\begin{array}{l}\text { Ingredients (kg/ton) } \\
\text { Yellow corn }\end{array}$} & \multicolumn{2}{|c|}{ Starter Diets } & \multicolumn{2}{|c|}{ Finisher Diets } \\
\hline & 564.0 & 564.0 & 680.0 & 680.0 \\
\hline Soybean meal, $44 \%$ & 383.0 & 383.0 & 267.0 & 267.0 \\
\hline Dicalcium phosphate & 20.0 & 20.0 & 20.0 & 20.0 \\
\hline Sunflower oil & 15.0 & 15.0 & 15.0 & 15.0 \\
\hline Limestone & 10.0 & 9.58 & 10.0 & 9.58 \\
\hline Zinc Oxide & 0.0 & 0.420 & 0.0 & 0.420 \\
\hline Salt & 3.0 & 3.0 & 3.0 & 3.0 \\
\hline Vit+Min premix * & 3.0 & 3.0 & 3.0 & 3.0 \\
\hline DL-methionine & 1.0 & 1.0 & 1.0 & 1.0 \\
\hline Antifungal & 1.0 & 1.0 & 1.0 & 1.0 \\
\hline \multicolumn{5}{|l|}{ Composition (calculated values) } \\
\hline Metabolizable energy, MJ/kg & 12.05 & 12.05 & 12.60 & 12.60 \\
\hline Methionine, $\mathrm{g} / \mathrm{kg}$ & 4.4 & 4.4 & 3.9 & 3.9 \\
\hline Methionine + Cysteine (SSA), g/kg & 7.9 & 7.9 & 6.9 & 6.9 \\
\hline Lysine $\mathrm{g} / \mathrm{kg}$ & 11.8 & 11.8 & 9.0 & 9.0 \\
\hline Calcium $\mathrm{g} / \mathrm{kg}$ & 9.5 & 9.5 & 9.2 & 9.2 \\
\hline Available phosphorous $\mathrm{g} / \mathrm{kg}$ & 4.5 & 4.5 & 4.3 & 4.3 \\
\hline \multicolumn{5}{|l|}{ Composition (measured values) } \\
\hline Dry matter, $\mathrm{g} / \mathrm{kg}$ & 894.1 & 894.1 & 897.5 & 897.5 \\
\hline Crude protein, $\mathrm{g} / \mathrm{kg}$ & 212.6 & 212.6 & 173.6 & 173.6 \\
\hline Ether extract, $\mathrm{g} / \mathrm{kg}$ & 42.1 & 42.1 & 43.8 & 43.8 \\
\hline Crude fiber, $\mathrm{g} / \mathrm{kg}$ & 46.1 & 46.1 & 46.2 & 46.2 \\
\hline Ash, $\mathrm{g} / \mathrm{kg}$ & 77.0 & 77.0 & 78.4 & 78.4 \\
\hline Nitrogen free extract, $\mathrm{g} / \mathrm{kg}$ & 593.3 & 593.3 & 633.9 & 633.9 \\
\hline $\mathrm{Zn}, \mathrm{ppm}$ & 26.0 & 26.0 & 26.0 & 26.0 \\
\hline
\end{tabular}

* Vit + Min Premix provides the following (per kg of diet): Vitamin A, $1800 \mathrm{mg}$ retinol; Vitamin E, $6.67 \mathrm{mg}$ d-alpha-tocopherol; menadione, $2.5 \mathrm{mg}$; Vit D3, $50 \mathrm{mcg}$ cholecalciferol; riboflavin, $2.5 \mathrm{mg}$; Ca pantothenate, $10 \mathrm{mg}$; nicotinic acid, $12 \mathrm{mg}$; choline chloride, $300 \mathrm{mg}$; vitamin B12, $4 \mathrm{mcg}$; vitamin B6, $5 \mathrm{mg}$; thiamine, $3 \mathrm{mg}$; folic acid, 0.50 $\mathrm{mg}$; biotin $0.2 \mathrm{mg}$; Mn, $80 \mathrm{mg}$; Fe, $40 \mathrm{mg}$; Cu, $4 \mathrm{mg}$; Se, $0.10 \mathrm{mg}$.

Each diet was fed to five replicates consisting of nine male WPD each. Each replicate was housed in floor pens $(1.0 \mathrm{~m} \times 2 \mathrm{~m})$ furnished with wood shavings. The brooding temperature was 34,32 , 30 and $28^{\circ} \mathrm{C}$ during Weeks 1, 2, 3 and 4, respectively, and thereafter the temperature inside the house was about $27^{\circ} \mathrm{C}$. The light program provided $24 \mathrm{~h}$ of light on the first day; and then the lighting was gradually reduced to $10 \mathrm{~h} /$ day at 21 days of age. The light was supplied continuously. Water and mash form of feed were offered ad libitum.

\subsection{Data Collection}

The ducks were individually weighed at 1,28 , and 56 days of age in the morning, before offering feed. The remaining, scattered and consumed feed were measured during the periods 1-28, 28-56 and 1-56 days for each replicate; thus, the average feed intake per bird was calculated as the ratio between feed intake and the number of ducks per replicate. The feed conversion ratio (FCR) was calculated as units of feed intake required to produce one unit of gain in live body weight in the periods 1-28, $28-56$ and 1-56 days. The mortality rate was recorded along the entire experimental period. At the end of the trial (56 days of age), five birds per treatment were randomly chosen, weighed after being fasted overnight, and slaughtered according to the Islamic guidelines. Feathers were plucked, the inedible parts (head, feet, and inedible viscera) were removed and the remaining (dressed) carcass was weighed. The feathers, liver, spleen, gizzard, heart, pancreas, and abdominal fat were separated and individually weighed. The percentage carcass yield and the percentages of internal organ weights relative to live body weight were calculated. A 50/50 (w/w) sample of skinless breast and thigh meat 
was weighed and kept in an electric drying oven at $70{ }^{\circ} \mathrm{C}$ until a constant weight was reached. The dried flesh was finely ground through a suitable mixer, passed through a sieve $\left(1 \mathrm{~mm}^{2}\right)$, and then carefully mixed and stored in tightly sealed glass containers for subsequent analysis. The physical characteristics of a sample mixture of breast and thigh meats were evaluated. The ability of meat to hold water (WHC) and meat tenderness were measured according to the methods of Volvoinskaia and Kelman [19]. The $\mathrm{pH}$ was measured as described by Aitken et al. [20]. The color intensity (optical density) of meat was determined according to the method of Husani et al. [21].

At 56 days of age, five ducks per group were housed in individual cages and used to evaluate the nutrient digestibility of the experimental diets. The birds were housed in individual cages. The methodology involved a four-day adaptation period followed by a three-days excreta collection period. After each day of collection, the excreta samples were dried to come to equilibrium with the atmosphere, weighed, ground and, finally, mixed together and stored in screw-top glass jars until analysis. The proximate chemical composition of the feed and excreta was according to the official methods of Association of Official Analytical Chemists (AOAC) [18].

The Zinc content was determined after ashing of the samples with $10 \mathrm{~mL}$ of concentrated sulfuric acid. Three drops of bichloric acid were added and the samples were incubated at room temperature for $2 \mathrm{~h}$. Zinc concentration in the diets, liver, bones, excreta, and plasma were determined by atomic absorption spectroscopy (GBC Avanta Z, GBC Scientific Equipment, Braeside, Australia) using a standard curve. The apparent retention of $\mathrm{Zn}$ was calculated by dividing the difference between the amount consumed and that excreted by the amount consumed.

Blood samples were collected from wing vein from five ducks per treatment and placed into heparinized tubes. The plasma was separated by centrifugation at $1500 \times g$ for $15 \mathrm{~min}$ and stored at $-18{ }^{\circ} \mathrm{C}$ until analysis. The plasma levels of $\mathrm{Zn}$ and $\mathrm{Cu}$ were determined by atomic absorption spectrometry after processing the samples as previously described.

\subsection{Statistical Analysis}

The data were analyzed using a two-way ANOVA of the General Linear Model (GLM) procedure of SAS [22] in which Zn and phytase supplementations were the main effects. The potential interactions between the effects were also evaluated. A probability of less or equal to 0.05 was considered significant, based on the Student Newman-Keuls Test of mean differences among treatments [22]. The data are reported based on the main effects and significant interactions. The differences among mortality rate were analyzed by chi-square test.

\section{Results}

The grower and the finisher basal diets used in the trial contained $26 \mathrm{ppm}$ of $\mathrm{Zn}$ from raw materials (Table 1) as determined by atomic absorption spectrometry. The data on in vivo performance are reported in Table 2.

The mortality rate was not statistically different among the experimental groups. The addition of $30 \mathrm{ppm}$ of $\mathrm{Zn}$ to the basal diets increased the body weight gain $(p<0.01)$ and feed intake $(p<0.05)$, and improved the FCR $(p<0.05)$ of ducks considering the entire period of the trial. The supplementation of phytase also improved $(p<0.01)$ BWG and FCR from 1 to 56 days, but the feed intake was not different from the control group. Except for the feed intake, the interaction between the two tested factors was significant: when no $\mathrm{Zn}$ was included in the diet, the addition of phytase improved both FCR and BWG; however, when $30 \mathrm{ppm}$ of $\mathrm{Zn}$ were added to the basal diet, the addition of phytase did not improve the duck performance.

The addition of $\mathrm{Zn}$ to the diets reduced $(p<0.01) \mathrm{Zn}$ retention (Table 3) and increased the level of Zn in tibia $(p<0.01)$, liver $(p<0.05)$ and excreta $(p<0.01)$. 
Table 2. Effect of zinc supplementation, with and without phytase addition, on body weight gain, feed intake and feed conversion ratio of ducks *

\begin{tabular}{|c|c|c|c|c|c|c|c|c|c|c|}
\hline \multirow{3}{*}{ Treatment Group } & \multicolumn{3}{|c|}{ BWG (g/Bird/Period) } & \multicolumn{3}{|c|}{ Feed Intake (g/Bird/Period) } & \multicolumn{3}{|c|}{ FCR (g/Bird/Period) } & \multirow{3}{*}{ Dead $(n)$} \\
\hline & $1-28$ & $29-56$ & 1-56 & $1-28$ & $29-56$ & $1-56$ & 1-28 & 29-56 & $1-56$ & \\
\hline & Day & Day & Day & Day & Day & Day & Day & Day & Day & \\
\hline 0 ppm & $1010^{\mathrm{b}}$ & $916^{\mathrm{b}}$ & $1926^{b}$ & $1931^{\mathrm{b}}$ & $4182^{b}$ & $6114^{\mathrm{b}}$ & 1.91 & 4.59 & $3.18^{\mathrm{a}}$ & 3 \\
\hline $30 \mathrm{ppm}$ & $1079^{\mathrm{a}}$ & $965^{\mathrm{a}}$ & $2044^{a}$ & $1991^{\mathrm{a}}$ & $4307^{\mathrm{a}}$ & $6297^{a}$ & 1.85 & 4.46 & $3.08^{\mathrm{b}}$ & 1 \\
\hline $500 \mathrm{U} / \mathrm{kg}$ diet & 1056 & $970^{a}$ & $2026^{a}$ & 1960 & 4242 & 6202 & 1.86 & $4.38^{\mathrm{b}}$ & $3.06^{\mathrm{b}}$ & 2 \\
\hline \multicolumn{11}{|c|}{ Interaction between $\mathrm{Zn}$ and phytase } \\
\hline $\begin{array}{l}0 \text { ppm } Z n+0 U \\
\text { phytase }\end{array}$ & $974^{\mathrm{d}}$ & $855^{b}$ & $1830^{\mathrm{b}}$ & 1937 & 4189 & 6126 & $1.99^{\mathrm{a}}$ & $4.90^{\mathrm{a}}$ & $3.35^{\mathrm{a}}$ & 2 \\
\hline $\begin{array}{l}0 \text { ppm } \mathrm{Zn}+500 \mathrm{U} \\
\text { phytase }\end{array}$ & $1045^{c}$ & $976^{a}$ & $2021^{a}$ & 1924 & 4175 & 6100 & $1.84^{\mathrm{b}}$ & $4.28^{b}$ & $3.02^{b}$ & 1 \\
\hline \multicolumn{11}{|l|}{$p$ value } \\
\hline Zn addition & 0.0003 & 0.0023 & 0.0004 & 0.0295 & 0.0364 & 0.0336 & 0.1071 & 0.0711 & 0.0471 & NS \\
\hline Phytase inclusion & 0.1191 & 0.0005 & 0.0007 & 0.9529 & 0.9221 & 0.9323 & 0.2344 & 0.0021 & 0.0077 & NS \\
\hline Interaction & 0.0069 & 0.004 & 0.0002 & 0.6578 & 0.8849 & 0.8089 & 0.0289 & 0.0022 & 0.0012 & NS \\
\hline RMSE & 33.15 & 30.6 & 45.17 & 55.23 & 121.6 & 176.5 & 0.094 & 0.149 & 0.105 & 0.94 \\
\hline
\end{tabular}

* $n=180$ bird as 45 bird per treatment group for body weight gain and $n=20$ replicates as five replicates per each treatment for feed intake and feed conversion ratio. RMSE, Root mean square error. ${ }^{a-d}$ means with different superscripts in the same column in similar treatment group are significantly different; NS, not significant. 
Table 3. Effect of zinc supplementation, with and without phytase addition, on $\mathrm{Zn}$ retention and tissue and excrement concentrations, and plasma $\mathrm{Zn}$ and $\mathrm{Cu}$ concentrations in White Pekin ducks *.

\begin{tabular}{|c|c|c|c|c|c|c|c|}
\hline & Zn Retention (\%) & Tibia Ash (\%) & $\begin{array}{l}\text { Tibia Zn } \\
\text { (ppm) }\end{array}$ & $\begin{array}{l}\text { Liver Zn } \\
(\text { ppm) }\end{array}$ & $\begin{array}{l}\text { Excrement Zn } \\
(\text { ppm })\end{array}$ & $\begin{array}{l}\text { Plasma Zn } \\
(\mathrm{mg} / 100 \mathrm{~mL})\end{array}$ & $\begin{array}{c}\text { Plasma Cu } \\
(\mathrm{mg} / 100 \mathrm{~mL})\end{array}$ \\
\hline \multicolumn{8}{|l|}{ Zn addition } \\
\hline 0 ppm & $37.67^{\mathrm{a}}$ & 44.65 & $161.3^{\mathrm{b}}$ & $61.3^{\mathrm{b}}$ & $72.15^{\mathrm{b}}$ & $160.1^{\mathrm{b}}$ & $6.61^{\mathrm{b}}$ \\
\hline 30 ppm & $35.17^{b}$ & 45.13 & $165.4^{\mathrm{a}}$ & $63.4^{\mathrm{a}}$ & $160.0^{\mathrm{a}}$ & $189.3^{\mathrm{a}}$ & $7.22^{\mathrm{a}}$ \\
\hline \multicolumn{8}{|l|}{ Phytase inclusion } \\
\hline $0 \mathrm{U} / \mathrm{kg}$ diet & 35.90 & 45.15 & $162.8^{b}$ & $61.0^{\mathrm{b}}$ & $117.6^{\mathrm{a}}$ & $164.9^{\mathrm{b}}$ & $5.93^{b}$ \\
\hline $500 \mathrm{U} / \mathrm{kg}$ diet & 36.96 & 44.63 & $164.0^{\mathrm{a}}$ & $63.7^{\mathrm{a}}$ & $114.3^{b}$ & $184.0^{\mathrm{a}}$ & $8.28^{\mathrm{a}}$ \\
\hline \multicolumn{8}{|c|}{ Interaction between $\mathrm{Zn}$ and phytase } \\
\hline 0 ppm Zn +0 U phytase & 36.64 & $44.46^{\mathrm{b}}$ & 160.6 & 60.7 & 74.06 & $149.2^{\mathrm{d}}$ & $5.23^{\mathrm{d}}$ \\
\hline 0 ppm Zn +500 U phytase & 38.70 & $44.91^{\mathrm{a}}$ & 161.9 & 61.8 & 70.06 & $169.0^{c}$ & $7.97^{b}$ \\
\hline 30 ppm Zn + 0 U phytase & 35.12 & $45.91^{\mathrm{a}}$ & 165.0 & 61.4 & 161.2 & $180.7^{\mathrm{b}}$ & $6.63^{c}$ \\
\hline 30 ppm Zn +500 U phytase & 35.22 & $44.36^{\mathrm{b}}$ & 165.7 & 65.5 & 158.4 & $197.6^{\mathrm{a}}$ & $8.60^{\mathrm{a}}$ \\
\hline \multicolumn{8}{|l|}{$p$ value } \\
\hline Zn addition & 0.0008 & 0.2795 & 0.0001 & 0.0367 & 0.0001 & 0.0001 & 0.0001 \\
\hline Phytase concentration & 0.0918 & 0.2429 & 0.0458 & 0.0126 & 0.0001 & 0.0001 & 0.0001 \\
\hline Interaction & 0.1232 & 0.0302 & 0.5068 & 0.1378 & 0.4466 & 0.0006 & 0.0001 \\
\hline RMSE & 1.346 & 0.958 & 1.072 & 2.12 & 1.491 & 0.736 & 0.164 \\
\hline
\end{tabular}

* $n=20$ samples as five sample per each treatment. RMSE, Root mean square error. ${ }^{\text {a-d }}$ means with different superscripts in the same column in similar treatment groups are significantly different; NS, not significant. 
In addition, the level of $\mathrm{Zn}$ and $\mathrm{Cu}$ in the plasma increased $(p<0.01)$ due to $\mathrm{Zn}$ inclusion in the basal diets. The addition of phytase increased the level of $\mathrm{Zn}$ in tibia $(p<0.05)$ and liver $(p<0.01)$ as well as the concentration of $\mathrm{Zn}$ and $\mathrm{Cu}$ in plasma $(p<0.01)$ but decreased the $\mathrm{Zn}$ content in the excreta $(p<0.01)$. The interaction between $\mathrm{Zn}$ level and phytase was significant for tibia ash, plasma $\mathrm{Zn}$ and plasma $\mathrm{Cu}$. The use of phytase significantly decreased the tibia ash when $30 \mathrm{ppm}$ of $\mathrm{Zn}$ oxide were added to the diets, but it did not happen for the $\mathrm{Zn}$-free diet. The addition of phytase to the basal diet increased $\mathrm{Zn}$ and $\mathrm{Cu}$ concentration by $13.4 \%$ and $34.4 \%$, respectively, while the addition of phytase to $30 \mathrm{ppm} \mathrm{Zn}$ diets increased the $\mathrm{Zn}$ and $\mathrm{Cu}$ plasma levels by $9.4 \%$ and $29.7 \%$, respectively.

The addition of $\mathrm{Zn}$ to the basal diet decreased $(p<0.01)$ the percentage of gizzard but the other carcass traits were unaffected (Table 4$)$. The use of phytase decreased the percentage of liver $(p<0.01)$ and abdominal fat $(p<0.01)$. There was a significant interaction between $\mathrm{Zn}$ level and phytase supplementation on gizzard percentage. Results indicate that phytase increased gizzard percentage of ducks fed 30 ppm Zn diet but had no effect when added to the basal diets. 
Table 4. Effect of zinc supplementation, with and without phytase addition, on the percentage weights of the dressed carcass, carcass parts, inner organs, and abdominal fat in White Pekin ducks *

\begin{tabular}{|c|c|c|c|c|c|c|c|c|c|}
\hline & Dressing $(\%)$ & Front Part (\%) & Hind Part (\%) & Pancreas $(\%)$ & Spleen $(\%)$ & Liver $(\%)$ & Gizzard (\%) & Heart $(\%)$ & Abdominal Fat (\%) \\
\hline \multicolumn{10}{|l|}{ Zn addition } \\
\hline $0 \mathrm{ppm}$ & 65.4 & 41.4 & 24 & 0.333 & 0.061 & 2.25 & $3.79^{\mathrm{a}}$ & 0.66 & 0.618 \\
\hline $30 \mathrm{ppm}$ & 65.5 & 41.7 & 23.8 & 0.388 & 0.050 & 2.17 & $3.05^{\mathrm{b}}$ & 0.616 & 0.641 \\
\hline \multicolumn{10}{|l|}{ Phytase concentration } \\
\hline $0 \mathrm{U} / \mathrm{kg}$ diet & 66.6 & 42.3 & 24.2 & 0.352 & 0.055 & $2.39^{\mathrm{a}}$ & 3.42 & 0.638 & $0.790^{\mathrm{a}}$ \\
\hline $500 \mathrm{U} / \mathrm{kg}$ diet & 64.4 & 40.7 & 23.7 & 0.369 & 0.056 & $2.03^{b}$ & 3.41 & 0.614 & $0.472^{\mathrm{b}}$ \\
\hline \multicolumn{10}{|c|}{ Interaction between $\mathrm{Zn}$ and phytase } \\
\hline $0 \mathrm{ppm} \mathrm{Zn}+0 \mathrm{U}$ phytase & 67.5 & 43.1 & 24.4 & 0.373 & 0.058 & 2.31 & $4.02 \mathrm{a}$ & 0.693 & 0.820 \\
\hline 0 ppm Zn +500 U phytase & 63.4 & 39.7 & 23.7 & 0.291 & 0.064 & 2.18 & $3.56^{a, b}$ & 0.626 & 0.413 \\
\hline 30 ppm Zn + 0 U phytase & 65.6 & 41.6 & 23.9 & 0.332 & 0.051 & 2.46 & $2.83^{c}$ & 0.622 & 0.748 \\
\hline 30 ppm Zn + 500 U phytase & 65.4 & 41.7 & 23.7 & 0.446 & 0.048 & 1.88 & $3.26^{\mathrm{b}}$ & 0.602 & 0.530 \\
\hline \multicolumn{10}{|l|}{$p$ value } \\
\hline Zn addition & 0.9343 & 0.1353 & 0.7878 & 0.3446 & 0.075 & 0.5699 & 0.0001 & 0.5213 & 0.6869 \\
\hline Phytase concentration & 0.0941 & 0.0729 & 0.4483 & 0.7761 & 0.8531 & 0.0123 & 0.9465 & 0.2596 & 0.0001 \\
\hline Interaction & 0.1293 & 0.0602 & 0.7413 & 0.1188 & 0.4321 & 0.093 & 0.0288 & 0.5684 & 0.9421 \\
\hline RMSE & 2.712 & 1.881 & 1.548 & 0.132 & 0.013 & 0.28 & 0.413 & 0.255 & 0.119 \\
\hline
\end{tabular}

${ }^{*} n=20$ samples as five sample per each treatment; RMSE, Root mean square error. ${ }^{\text {a-d }}$ means with different superscripts in the same column in similar treatment groups are significantly different; NS, not significant. 


\section{Discussion}

The natural presence of $\mathrm{Zn}$ in the diets from the raw materials is not enough alone to adequately sustain the duck growth. In our trial, the addition of $30 \mathrm{ppm}$ of $\mathrm{Zn}$ oxide to the basal diets improved the animal performance: the increase of feed intake was responsible for the increased body weight gain, giving a more favorable FCR. Cufadar and Bahtiyarca [23] indicated that $30 \mathrm{ppm}$ of $\mathrm{Zn}$ was adequate for growth performance of male WPD. The live weight of the ducks at the end of the trial (56 days) was lower than the data recorded in the literature. However, as reported by Dodu [24], the imported breed of ducks, along the years, was mixed with local populations giving genetic lines differing for some growing characteristics from the original breed. In particular, Dodu [24] indicated that the body weight at 56 days of some Pekin ducks bred in Romania was around $2 \mathrm{~kg}$. In a previous study, Attia et al. [25] found similar body weight for 56-day-old Pekin ducks breed in Egypt.

The supplementation of $\mathrm{Zn}$ to the basal diet strongly increased its amount in the excreta, also due to the lowering of the retention rate. In fact, the primary mechanism of trace minerals homeostasis is the modification of the trace minerals absorption and excretion in the gut [25-27]. Cao et al. [28] observed that bone and fecal $\mathrm{Zn}$ contents were significantly increased when the diets of chickens were supplemented with organic and inorganic sources of $\mathrm{Zn}$. The significant increase of gizzard percentage due to the addition of $\mathrm{Zn}$ in the present trial could be justified by the increased feed intake which could play a physical effect on gizzard expansion.

The improved BWG and FCR in ducks supplemented with phytase diets were not due to an increase of feed intake: in fact, the percentage of gizzard was also unchanged between the groups. The positive effect of phytase on growth performance of WPD could be attributed to the increase in the availability of others inorganic and organic nutrients [14,29-31]. The positive effect of Zn on BWG was probably due to an improved activity of the copper-requiring metalloenzymes, such as ceruloplasmin, cupro-zinc superoxide dismutase and cytochrome c oxidase, which have a very important role as anti-oxidants in the metabolism [32]. In addition, looking at the interaction effect, the use of the basal diet without $\mathrm{Zn}$ supplementation induced lower growth rate than that with an addition of $500 \mathrm{U}$ of phytase or $30 \mathrm{ppm}$ of $\mathrm{Zn}$. The increased growth rate due to phytase or $\mathrm{Zn}$ supplementation resulted in an improved FCR. The phytase improved $\mathrm{Zn}$ utilization, as evidenced by the increase of $\mathrm{Zn}$ in plasma and its decrease in the excreta, but the effect on $\mathrm{Zn}$ retention was weak. In the literature, the effect of phytase on Zn availability is contradictory: phytase is reported to increase the availability of dietary $\mathrm{Zn}[4,23]$ as well as the bone $\mathrm{Zn}$ content in pigs and chicks [33], but to have no significant effect on $\mathrm{Zn}$ digestibility and apparent absorption percentage of $\mathrm{Zn}, \mathrm{Fe}$, or $\mathrm{Cu}$ in chicks [34]. These differences could be ascribed to the differences in the metabolism among the species, the different dietary composition or $\mathrm{Zn}$ level in the basal diet. Dietary $\mathrm{Zn}$ at $800 \mathrm{ppm}$ negatively affected phytate breakdown by phytase [35] as a result of a conformational change in the phytate moiety, thereby making it less accessible to phytase.

The effect of phytase on plasma Zn content was stronger in WPD fed the basal diet than in those fed diets supplemented with $30 \mathrm{ppm}$ of $\mathrm{Zn}$ oxide (13.3\% vs. $9.4 \%)$. These results are consistent with those reported by Mohana and Nys [36]. In addition, the value for Zn retention found herein agrees with those reported by other authors [10,36]. Similar to the present findings, Jondreville et al. [15] found that $100 \mathrm{FTU}$ of phytase were equal to $1 \mathrm{ppm}$ of $\mathrm{Zn}$, and that the $\mathrm{Zn}$ excretion could be reduced by $10 \%$ if a corn-soybean diet were supplemented with $500 \mathrm{FTU}$ phytase $/ \mathrm{kg}$ diet.

In the present study, the phytase significantly increased plasma content of $\mathrm{Cu}$, according to Attia et al. [37,38]. Revy et al. [30] reported a positive effect of phytase on $\mathrm{Cu}$ availability due to the effect of phytase on phytate-mineral complex formation. However, Jondreville et al. [15] reported that microbial phytase had a negative effect on the liver $\mathrm{Cu}$ content in chicks and pigs, likely because of the negative effect of $\mathrm{Zn}$ on $\mathrm{Cu}$ availability due to release of $\mathrm{Zn}$ by phytase [39].

The lower percentage of the abdominal fat and liver in WPD fed diets with phytase may be attributed to the reapportioning of nutrients towards growth rather than fat accumulation. Similar results were reported by Attia et al. [12,29]. Furthermore, Cufadar and Bahtiyarca [23] reported that 
increasing dietary phytase at three dietary Zn levels increased the results for all carcass parameters, although the effects were not proportional to the level of dietary phytase; rather, phytase prevented the deleterious effects of dietary $\mathrm{Zn}$ on carcass traits. This might explain the positive effect of phytase on the growth and the decrease of the abdominal fat of WPD in the present study. Orban et al. [40], Attia et al. [12,29] and Cufadar and Bahtiyarca [23] found that phytase significantly increased the carcass weight, neck, thigh, back + breast and wings of broilers.

\section{Conclusions}

The natural presence of $\mathrm{Zn}$ in raw materials is not enough alone to satisfy the $\mathrm{Zn}$ requirements of the growing ducks. The addition of $30 \mathrm{ppm}$ of $\mathrm{Zn}$ or $500 \mathrm{U}$ of phytase to the basal diet increased the growth rate and improved the FCR of the ducks. However, the addition of $30 \mathrm{ppm}$ of $\mathrm{Zn}$ oxide also increased the level of $\mathrm{Zn}$ in the excreta, while the addition of $500 \mathrm{U}$ of phytase had an opposite effect and is more appropriate to reduce the potential risks for environmental pollution.

Author Contributions: Conceptualization, Y.A.A.; Data curation, A.A.-H.E.A.A.-H. and F.B.; Investigation, Y.A.A.; Supervision, Y.A.A.; Writing-original draft, A.A.-H.E.A.A.-H.; Writing-review \& editing, N.F.A. and F.B.

Funding: This article was funded by the Deanship of Scientific Research (DSR), King Abdulaziz University, Jeddah. The authors, therefore, acknowledge with thanks the Deanship of Scientific Research for technical and financial support.

Acknowledgments: The authors thank the late Hassan Saber Zeweil, Department of Animal and Fish Production, Faculty of Agriculture (Saba Basha), Alexandria University, and late Mohamed Drawish Sahledom, Secondary School of Agriculture, Damanhour, Ministry of Education, for their help and support during data collection and Lab analyses.

Conflicts of Interest: The authors declare no conflict of interest.

\section{References}

1. MacDonald, R.S. The role of zinc in growth and cell proliferation. J. Nutr. 2000, 130, 1500s-1508s. [CrossRef]

2. Mayer, A.N.; Vieira, S.L.; Berwanger, E.; Angel, C.R.; Kindlein, L.; Franca, I.; Noetzold, T.L. Zinc requirements of broiler breeder hens. Poult. Sci. 2019, 98, 1288-1301. [CrossRef]

3. NRC. Nutrient Requirements of Poultry, 9th ed.; National Research Council, National Academy Press: Washington, DC, USA, 1994.

4. Roberts, J.R. Factors affecting egg internal quality and eggshell quality in laying hens. J. Poult. Sci. 2004, 41, 161-177. [CrossRef]

5. Navidshad, B.; Jabbari, S.; Gheshiagh, F.M.A. The new progresses in Zn requirements of poultry. Iran. J. Appl. Anim. Sci. 2016, 6, 763-767.

6. Underwood, E.J.; Suttle, N.F. The Mineral Nutrition of Livestock; CABI Publishing: New York, NY, USA, 1999.

7. O'Dell, B.L.; Savage, J.E. Effect of phytic acid on zinc availability. Exp. Biol. Med. 1960, 103, 304-306.

8. Stahl, L.; Greger, J.L.; Cook, M.E. Breeding-Hen and Progeny Performance When Hens Are Fed Excessive Dietary Zinc. Poult. Sci. 1990, 69, 259-263. [CrossRef]

9. Leeson, S. Nutrition \& health: Poultry. Feedstuffs 2009, 16, 45-52.

10. Zhang, T.Y.; Liu, J.L.; Zhang, J.L.; Zhang, N.; Yang, X.; Qu, H.X.; Xi, L.; Han, J.C. Effects of dietary zinc levels on the growth performance, organ zinc content, and zinc retention in broiler chickens. Braz. J. Poult. Sci. 2018, 20, 127-132. [CrossRef]

11. EFSA. Scientific opinion on the potential reduction of the currently authorised maximum contents of zinc in feed. EFSA J. 2014, 12, 3668.

12. Attia, Y.A.; Abd El-Rahman, S.A.; Qota, E.M.A. Effects of microbial phytase with or without cell-wall splitting enzymes on the performance of broilers fed suboptimum levels of dietary protein and metabolisable energy. Egypt. Poult. Sci. J. 2001, 21, 521-547.

13. Attia, Y.A.; Qota, E.M.A.; Bovera, F.; Tag El-Din, A.E.; Mansour, S.A. Effect of amount and source of manganese and/or phytase supplementation on productive and reproductive performance and some physiological traits of dual purpose-cross-bred hens in the tropics. Br. Poult. Sci. 2010, 51, 235-245. [CrossRef] 
14. Selle, P.H.; Ravindran, V. Microbial phytase in poultry nutrition. Anim. Feed Sci. Technol. 2007, 135, 1-41. [CrossRef]

15. Jondreville, C.; Lescoat, P.; Magnnin, M.; Feuerstein, D.; Gruenberg, B.; Nys, Y. Sparing effect of microbial phytase on zinc supplementation in maize-soybean meal diets for chickens. Animal 2007, 1, 804-811. [CrossRef]

16. Létourneau-Montminy, M.P.; Narcy, A.; Lescoat, P.; Bernier, J.F.; Magnin, M.; Pomar, C.; Nys, Y.; Sauvant, D.; Jondreville, C. Meta-analysis of phosphorus utilisation by broilers receiving corn-soyabean meal diets: Influence of dietary calcium and microbial phytase. Animal 2010, 4, 1844-1853. [CrossRef]

17. Yu, Y.; Lu, L.; Wang, R.L.; Xi, L.; Luo, X.G.; Liu, B. Effects of zinc source and phytate on zinc absorption by in situ ligated intestinal loops of broilers. Poult. Sci. 2010, 89, 2157-2165. [CrossRef]

18. AOAC. Official Methods of Analysis, 17th ed.; Association of Official Analytical Chemists: Arlington, VA, USA, 2000.

19. Volvoinskaia, V.R.; Kelman, B.Y. Modification of the WHC method of meat. Feed Ind. 1962, 11, 80-86.

20. Aitken, A.; Casey, J.C.; Penny, I.F.; Volys, C.A. Effect of drying temperature in the accelerated freeze drying of pork. J. Food Sci. 1962, 75, 505-513. [CrossRef]

21. Husani, S.A.; Deartherage, F.B.; Kunkle, L.E. Studies on meat. Observations on relation of biochemical factors to change in tenderness. Feed Technol. 1950, 4, 366-369.

22. SAS Institute Inc. Statistical Analytical System User's Guide; Version 6.12; SAS Institute Inc.: Cary, NC, USA, 1996.

23. Cufadar, Y.; Bahtiyarca, Y. Effect of an addition of phytase to diets with variable zinc and low phosphorus content on performance, carcass characteristics and bone mineralization of broilers. Rev. Med. Vet. 2004, 155, 355-361.

24. Dodu, M.A. Issues Concerning the Influence of Body Weight on the Duck Population (Anas Platyrhynchos Domesticus) Breeding Bihor Country. Analele UniversităNii din Oradea, Fascicula: Ecotoxicologie, Zootehnie şi Tehnologii de Industrie Alimentară. 2011. Available online: www.http://protmed.uoradea.ro/facultate/ anale/ecotox_zooteh_ind_alim/2011A/zoot/04.DODU\%201.pdf (accessed on 10 April 2017).

25. Attia, Y.A.; Abd Al-Hamid, A.E.; Zeweil, H.S.; Qota, E.M.; Bovera, F.; Monastra, G.; Sahledom, M.D. Effect of dietary amounts of inorganic and organic zinc on productive and physiological traits of White Pekin ducks. Animal 2013, 7, 895-900. [CrossRef]

26. Bao, Y.M.; Choct, M.; Ijip, A.; Bruerton, K. Effect of organically complexed copper, iron, manganese and zinc on broiler performance mineral excretion and accumulation in tissues. J. Poult. Sci. 2007, 16, 448-455. [CrossRef]

27. Attia, Y.A.; Qota, E.M.; Zeweil, H.S.; Bovera, F.; Abd Al-Hamid, A.E.; Sahledom, M.D. Effect of different dietary concentrations of inorganic and organic copper on growth performance and lipid metabolism of White Pekin male ducks. Br. Poult. Sci. 2012, 53, 77-88. [CrossRef] [PubMed]

28. Cao, J.; Henry, P.R.; Davis, S.R.; Cousins, R.J.; Miles, R.D.; Littell, R.C.; Ammerman, C.B. Relative bioavailability of organic zinc sources based on tissue zinc and metallothionine in chicks fed conventional dietary zinc concentrations. Anim. Feed Sci. Technol. 2002, 101, 161-170. [CrossRef]

29. Attia, Y.A.; Qota, E.M.A.; Aggoor, F.A.M.; Kies, A.K. Value for rice bran, its maximal utilization and its upgrading by phytase and other enzymes and diet-formulation based on available amino acids in the diet for broilers. Archiv Geflüg. 2003, 67, 157-166.

30. Revy, P.; Jondreville, S.C.; Dourmad, J.Y.; Nys, Y. Effect of zinc supplemented as either an organic or an inorganic source and of microbial phytase on zinc and other minerals utilization by weanling pigs. Anim. Feed Sci. Technol. 2004, 116, 93-112. [CrossRef]

31. Rodehutscord, M.; Hempel, R.; Wendt, P. Phytase effects on the efficiency of utilization and blood concentrations of phosphorus and calcium in Pekin ducks. Br. Poult. Sci. 2006, 47, 311-321. [CrossRef] [PubMed]

32. Labbe, M.R.; Fischer, W.F. The effect of high dietary zinc and copper deficiency on the activity of copper requiring metalloenzymes in the growing rat. J. Nutr. 1984, 114, 813-822. [CrossRef]

33. Zacharias, B.; Ott, H.; Drochner, W. The influence of dietary microbial phytase and copper on copper status in growing pigs. Anim. Feed Sci. Technol. 2003, 106, 139-148. [CrossRef] 
34. Veum, T.L.; Bollinger, D.W.; Buff, C.E.; Bedford, M.R. A genetically engineered Escherichia coli phytase improves nutrient utilization, growth performance, and bone strength of young swine fed diets deficient in available phosphorus. J. Anim. Sci. 2006, 84, 1147-1158. [CrossRef]

35. Augspurger, N.R.; Spencer, D.J.; Webel, M.D.; Baker, D.H. Pharmacological zinc levels reduce the phosphorus releasing efficacy of phytase in young pigs and chickens. J. Anim. Sci. 2004, 82, 1732-1739. [CrossRef]

36. Mohana, C.; Nys, Y. Effect of dietary zinc content and source on the growth, body zinc deposition and retention, zinc excretion, and immune response in chickens. Br. Poult. Sci. 1999, 40, 108-114. [CrossRef]

37. Attia, Y.A.; Abdalah, A.A.; Zeweil, H.S.; Bovera, F.; Tag El-Din, A.A.; Araft, M.A. Effect of inorganic or organic copper additions on reproductive performance, lipid metabolism and morphology of organs of dual-purpose breeding hens. Archiv Geflüg. 2011, 75, 169-178.

38. Attia, Y.A.; El-Tahawy, W.; Abd El-Hamid, A.E.; Hassan, S.; Nizza, A.; Elkelawy, M. Effect of phytase with or without multienzyme supplementation on performance and nutrient digestibility of young broiler chicks fed mash or crumble diets. Ital. J. Anim. Sci. 2012, 11, 303-308. [CrossRef]

39. Cousins, R.J. Absorption, transport, and intracellular metabolism of copper and zinc: Special reference to metallothionein and ceruloplasmin. Physiol. Rev. 1985, 65, 238-309. [CrossRef]

40. Orban, J.I.; Adeola, O.; Stroshine, R. Microbial phytase in finisher diets of white pekin ducks: Effect on growth performance, plasma phosphorus concentration, and leg bone characteristics. Poult. Sci. 1999, 78, 366-377. [CrossRef]

(C) 2019 by the authors. Licensee MDPI, Basel, Switzerland. This article is an open access article distributed under the terms and conditions of the Creative Commons Attribution (CC BY) license (http://creativecommons.org/licenses/by/4.0/). 